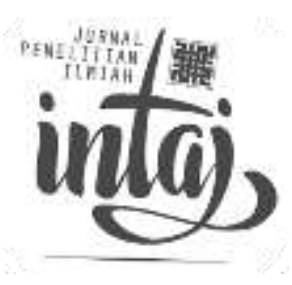

\title{
Analisis Keterampilan Berpikir Tingkat Tinggi dalam Menyelesaikan Soal UN Fisika SMA pada Materi Medan Magnet Siswa Kelas XII di SMA Muhammadiyah 3 Jember
}

\author{
Qurrotu A'yunina (qurrotuayunina.18@gmail.com) \\ Sudarti (sudarti.fkip@unej.ac.id) \\ Subiki (subiki.fkip@unej.ac.id) \\ Program Studi Pendidikan Fisika UniversitasJ ember
}

\begin{abstract}
This study aims to describe the high-level thinking skills of students in solving high school physics UN questions on magnetic field material. This research is a type of descriptive research with research subjects namely students of class XII MIPA M uhammadiyah 3 Jember High School. The data collection technique used was a written test consisting of five UN questions of magnetic field material that was modified in the form of descriptive questions. Based on the results of the study, the average percentage of high-level thinking skills of students in completing the National Examination (UN) questions on high school physics in magnetic field material is as follows: the analysis stage is $33.13 \%$, the evaluation stage is $29.77 \%$, and the creative stage is $21.05 \%$. The analysis phase has a large percentage so that it shows students are able to decipher information (known and asked) as well as steps to solve the problems given. W hile the creation stage has a low percentage so that it shows students are not accustomed to re-checking answers according to known data with coherent steps.
\end{abstract}

Keywords: higher order thinking ability, Physics UN, magnetic field material 


\section{PENDAHULUAN}

Pendidikan berperan penting dalam mngembangkan potensi siswa agar menjadi manusia yang beriman dan bertakwa kepada Tuhan Yang Maha Esa, berakhlak mulia, sehat, berilmu, cakap, kreatif, demokratis, serta bertanggung jawab. Tujuan dan fungsi pendidikan menjadi bermakna dalam perkembangan profesi tergantung pada model implementasi kurikulum pada pembalajaran di sekolah.

Fisika merupakan salah salah satu cabang sains yang berperan sangat penting dalam perkembangan ilmu pengetahuan dan teknologi. Namun berdasarkan data tentang pelaksanaan pembelajaran dan hasil nilai ujian nasional tahun 2015. Mata pelajaran fisika memiliki kecenderungan masih menempati nilai lebih rendah dari mata pelajaran lain. Samudra dalam penelitian permasalahan-permasalahan yang dihadapi siswa SMA dalam mempelajari Fisika bahwa penyebab siswa tidak menyukai pelajaran fisika antara lain: (1) siswa kesulitan memahami fisika karena materi pelajaran fisika padat; (2) siswa kesulitan memahami fisika karena pembelajarannya konstektual; (3) bahan ajar fisika tidak menarik dan membosankan.

Pembelajaran fisika adalah proses pemberian pengalaman belajar kepada siswa melalui serangkaian kegiatan yang terencana sehingga siswa memperoleh kompetensi tentang bahan fisika yang dipelajari. Salah satu kunci kesuksesan dalam belajar fisika adalah kemampuan tiga hasil pokok fisika, yaitu : a) konsepkonsep atau pengertian, b) prinsip-prinsip atau hukum atau azas, dan c) teori-teori atau model. Tiga pokok kemampuan didukung dengan tujuan pembelajaran fisika di Sekolah Menengah A tas (SMA) yaitu siswa memiliki kemampuan menguasai konsep dan prinsip fisika serta mempunyai keterampilan mengembangkan pengetahuan dan sikap percaya diri sebagai bekal untuk melanjutkan pendidikan pada jenjang yang lebih tinggi serta mengembangkan ilmu pengetahuan dan teknologi.

Perlu kiranya untuk mencapai tiga pokok kemapuan belajar fisika dan tujuan pembelajaran fisika melalui berlatih menyelesaikan fisika pada kehidupan sehari hari. Menyelesaikan permasalahan fisika dapat mengetahui seberapa jauh siswa memahami suatu materi. Hal ini sejalan dengan kompetensi dasar yang harus dicapai siswa dalam pembelajaran. Menurut Kemendikbud ${ }^{1}$, kompetensi dasar yang dimiliki siswa yaitu kompetensi dasar yang harus dimiliki siswa yaitu menunjukkan sikap logis, kritis, analitis, cermat, teliti, bertanggung jawab,

Kemendikbud, IImu Pengetahuan Alam, (Jakarta: KementerianPendidikan dan Kebudayaan, 2014) 
rersponsif, dan tidak mudah menyerah menyelesaikan masalah. Berdasarkan hal tersebut, dapat diketahui bahwa menyelesaikan permasalahan fisika merupakan salah satu bagian dari pembelajaran fisika. Menurut De Cock², karakter permasalahan diantaranya dapat ditunjukkan dengan format representasi soal yang disajikan. Sehingga, menyelesaikan permasalahan fisika dapat ditunjukkan dengan menyelesaikan soal-soal fisika salah satunya soal Ujian $\mathrm{N}$ asional (UN).

Siswa menyelesaikan permasalahan fisika berupa soal Ujian Nasional (UN) dituntut untuk menyelesaikan dengan langkah-langkah yang membutuhkan pemahaman. Kenyataannya masih dijumpai beberapa siswa yang mengalami kesulitan ketika memahami maksud dari masalah yang disajikan yang menjadikan siswa kurang mampu menyelesaikan permasalahan yang ada. Berdasarkan data puspendik (2017), nilai rata-rata Ujian Nasional (UN) pelajaran fisika dari 21 sekolah negeri di Kabupaten Jember pada tahun 2015 yaitu sebesar 76.86, tahun 2016 rata-rata nilai UN mata pelajaran fisika fisika menurun menjadi 62.18, sedangkan tahun 2017 nilai rata-rata UN mata pelajaran fisika di Kabupaten Jember mengalami penurunan menjadi 42.52. kemampuan siswa dalam menyelesaikan soal Ujian Nasional (UN) fisika menentukan nilai rata-rata Ujian Nasional (UN) tingkat Kabupaten Jember.

Salah satu penyebab rendahnya prestasi siswa ini dikarenakan lemahnya proses pembelajaran di Indonesia. Dalam proses pembelajaran, siswa kurang didorong untuk mengembangkan kemampuan berpikir. Namun, banyak pembelajaran fisika di kelas yang belum memanfaatkan keterampilan berpikir tingkat tinggi siswa juga mengemukakan bahwa salah satu kemampuan berpikir yang penting dikuasai oleh siswa adalah kemampuan berpikir tingkat tinggi.

A kan tetapi, seringkali kemampuan berpikir tingkat tinggi tersebut masih belum tercapai dengan baik, contohnya di SMA Muhammadiyah 3 Jember. Dari hasil survei dan wawancara di SMA Muhammadiyah 3 Jember, diperoleh informasi bahwa Kriteria Ketuntasan Minimal (KKM) untuk pelajaran matematika adalah 75, dimana 100\% siswa kelas XI M IPA 2 mendapatkan kategori tuntas. Dari soalsoal ulangan yang diberikan, terlihat bahwa soal tersebut masih jarang melatih kemampuan berpikir tingkat tinggi siswa. Ketika diberikan soal dengan level yang lebih tinggi, dari jawaban siswa terlihat bahwa kebanyakan siswa masih belum mampu menghubungkan, memanipulasi, dan mentransformasi pengetahuan serta

De Cock, Karakter Permasalahan Siswa dalam Penyelesaian Soal UN, (Jakarta: Rineka Cipta, 2012), hlm. 1 
pengalaman yang sudah dimiliki untuk berpikir kritis dan kreatif dalam upaya menentukan keputusan dan memecahkan masalah pada situasi baru.

Tujuan utama dari keterampilan berfikir tingkat tinggi adalah bagaimana meningkatkan kemampuan berfikir siswa pada level yang lebih tinggi, terutama yang berkaitan dengan kemampuan berfikir kritis dalam menerima segala jenis informasi, berpikir kreatif dalam memecahkan suatau masalah menggunakan pengetahuan yang dimiliki serta membuat keputusan dalam situasi-situasi yang kompleks ${ }^{3}$. Konsep dari keterampilan berfikir tingkat tinggi didasari oleh:

Tabel 1:

Dasar Konsep Keterampilan Berfikir Tingkat Tinggi

\begin{tabular}{|c|c|c|c|}
\hline $\begin{array}{c}\text { Problem Solving } \\
\text { Krulik \& Rudnick } \\
\text { (1998) }\end{array}$ & $\begin{array}{c}\text { Taksonomi Kognitif } \\
\text { Bloom Original } \\
\text { (1956) }\end{array}$ & $\begin{array}{l}\text { Taksonomi Bloom } \\
\text { Revisi Ander \& } \\
\text { Krathwohl (2001) }\end{array}$ & $\begin{array}{l}\text { Keterampilan } \\
\text { Berfikir Tingkat } \\
\text { Tinggi }\end{array}$ \\
\hline Recall & Knowledge & Remember & \\
\hline \multirow[t]{2}{*}{ Basic } & Comprehense & Understand & \\
\hline & Application & Apply & \\
\hline Critical & Analysis & Analize & Critical Thinking \\
\hline \multirow[t]{3}{*}{ Creative } & Synthesis & Evaluate & Creative Thinking \\
\hline & Evaluation & Create & Problem Solving \\
\hline & & & Decision M aking \\
\hline
\end{tabular}

Problem Solving menurut pandangan Krulik \& Rudnick ${ }^{4}$ adalah sebuah proses dimana setiap individual menggunakan pengetahuan yang diperoleh, keterampilan, pemahaman yang kemudian digunakan dalam situasi baru. Proses dimulai dengan membandingkan dan menyimpulkan kemudian siswa harus memadukan apa yang telah dipelajari dan menerapkan pada situasi baru. Pola pemecahan masalah menurut pandangan Krulik \& Rudnick dijabarkan dalam langkah - langkah yang dapat diajarkan kepada siswa, yaitu: (1) membaca sebuah permasalahan, (2) mengembangkan informasi, (3) memilih strategi, (4) menyelesaikan masalah, dan memeriksa kembali dan meluaskan.

Saputra, H. Dafik,. \& Diah, N. "Soal Matematika dalam PISA Kaitannya dengan Literasi Matematika dan Keterampilan Bepikir Tingkar Tinggi", dalam Proseeding Seminar Nasional Matematika, 2014

${ }^{4}$ S. Krulik, \& Rusnick, J. A, "Innovate Task to Improve Critical dan Creavtive Thinking Skill", dalam Stiff L.V. dan Curcio FR (ed.), Developing Mathematic Reasoning in Grades K-12, (Virginia: Yearbook NCTM, 1999), hlm. 138-145 
Terlihat pada tabel di atas, Bloom membagi domain kognitif menjadi enam level berfikir, yaitu: (1) knowledge atau pengetahuan tentang mengingat kembali informasi yang telah dipelajari, (2) comprehension atau memahami makna dari materi, (3) application atau menggunakan pengetahuan pada situasi baru dan situasi yang belum pernah dialami sebelumnya, (4) analysis atau mengidentifikasi dan memahami bagian-bagian materi atau keseluruhan materi, (5) synthesis atau menggabungkan elemen untuk membentuk keseluruhan yang baru, dan (6) evaluation atau memeriksa kembali dan menilai secara hati-hati berdasarkan beberapa kriteria.

Revisi taksonomi bloom yang dilakukan Anderson \& Krathwohl $^{5}$ lebih berfokus pada bagaimana domain kognitif lebih hidup dan aplikatif bagi pendidik dan praktik pembelajaran diharapkan dapat membantu pendidik untuk mengolah dan merumuskan tujuan pembelajaran dan strategi penilaian yang efisien. Ketiga konsep diatas yang menjadi dasar keterampilan berfikit tingkat tinggi merujuk pada aktivitas menganalisis, mengevaluasi, mencipta pengetahuan yang disesuaikan dengan konseptual, prosedural, dan metakognitif. Menurut Krathwohl ${ }^{6}$ dalam A revision of Bloom's Taxonomy, menyatakan bahwa indikator untuk mengukur keterampilan berfikir tingkat tinggi meliputi menganalisis (C4) yaitu kemampuan memisahkan konsep ke dalam beberapa komponen dan menghubungkan satu sama lain untuk memperoleh pemahaman atas konsep secara utuh, mengevaluasi (C5) yaitu kemampuan menetapkan derajat sesuatu berdasarkan norma, kriteria atau patokan tertentu, dan mencipta (C6) yaitu kemampuan memadukan unsure-unsur menjadi sesuatu bentuk baru yang utuh dan luas, atau membuat sesuatu yang orisinil.

Proses analisis soal adalah sebuah aktifitas yang memuat berbagai kegiatan yaitu: memilah, mengurai, membedakan sesuatu untuk digolongkan, dan dapat dikelompokkan menurut kriteria tertentu lalu dicari serta ditaksir makna dan kaitannya. Analisis dapat diartikan sebagai suatu kegiatan berpikir untuk menguaraikan suatu keseluruhan menjadi komponen, hubungan satu sama lain dan fungsi masing-masing dalam satu keseluruhan yang terpadu. Berdasarkan uraian tersebut maka dapat disimpulkan bahwa analisis keterampilan berpikir

W. W. Anderson, Krathwohl, D, R. A Taxonomy for Learning, Teaching, and Assissing: A Revision of Bloom's Taxonomy of Educational Objectives, (New York: Longman, 2001)

${ }^{6}$ Ibid 
tingkat tinggi merupakan kegiatan memilah, mengurai, dan membedakan suatu keterampilan untuk digolongkan dan dikelompokkan menurut kriteria tertentu.

Langkah-langkah menganalisis keterampilan berpikir tingkat tinggi siswa dalam menyelesaikan soal sebagai berikut: (a) Mengumpulkan data hasil tes siswa dalam menyelesaikan soal yang telah diberikan; (b) Mengidentifikasi dan mengklasifikasikan kemampuan siswa dalam menyelesaikan soal dengan cara menskor sesuai indikator yang ditetapkan; dan (c) Membuat presentase kemampuan siswa dalam menyelesaikan soal sesuai dengan tahapan keterampilan berpikir tingkat tinggi

Menurut Hadi Sutarto dan Radiyatul, ${ }^{7}$ beberapa indikator keterampilan menyelesaikan soal yang telah ditentukan akan diadopsi untuk menjadi pedoman indikator keterampilan siswa menyelesaikan soal dalam penelitian ini. Hal ini dikarenakan untuk menyesuaikan dengan karakteristik materi medan magnet yang telah dipilih, lebih jelasnya tertera dalam Tabel 2

\section{Tabel 2}

Jenis dan Indikator Keterampilan Berpikir Tingkat Tinggi Siswa dalam M enyelesaikan Soal

\begin{tabular}{|c|c|c|}
\hline Tahapan & Indikator & Skor \\
\hline \multirow[t]{5}{*}{ Menganalisis } & $\begin{array}{l}\text { Mampu menguraikan informasi (diketahui dan ditanya) } \\
\text { dari soal dan memformulasikan langkah-langkah } \\
\text { penyelesaian soal dengan tepat }\end{array}$ & 4 \\
\hline & $\begin{array}{l}\text { Mampu menguraikan informasi (diketahui dan ditanya) } \\
\text { dari soal dengan tepat, namun terdapat kesalahan dalam } \\
\text { memformulasikan langkah-langkah penyelesaian soal. }\end{array}$ & 3 \\
\hline & $\begin{array}{l}\text { Mampu menguraikan informasi (diketahui dan ditanya) } \\
\text { dari soal dengan tepat namun belum mampu } \\
\text { menformulasikan langkah-langkah penyelesaian soal. }\end{array}$ & 2 \\
\hline & $\begin{array}{l}\text { Belum mampu menguraikan informasi (diketahui dan } \\
\text { ditanya) dari soal dan memformulasikan langkah-langkah } \\
\text { penyelesaian soal dengan tepat. }\end{array}$ & 1 \\
\hline & Tidak mampu melakukan proses analisis sama sekali & 0 \\
\hline \multirow[t]{2}{*}{ Mengevaluasi } & $\begin{array}{l}\text { Mampu menyelesaikan langlah-langkah penyelesaian soal } \\
\text { dan memberikan kesimpulan dengan tepat }\end{array}$ & 4 \\
\hline & $\begin{array}{l}\text { M ampu menyelesaikan langkah-langkah penyelesaian soal } \\
\text { namun terdapat kesalahan dalam memberikan kesimpulan. }\end{array}$ & 3 \\
\hline
\end{tabular}

Sutarto Hadi dan Radiyatul, "Metode Pemecahan Masalah untuk Mengembangkan Kemampuan Siswa dalam Pemecahan Masalah Matematis di Sekolah Menengah Pertama", Jurnal Pendidikan Matematika. Vol. 2(1) 2014, hlm. 56-57 


\begin{tabular}{|c|c|c|}
\hline & $\begin{array}{l}\text { M ampu menyelesaiakan langkah-langkah penyelesaian soal } \\
\text { dengan tepat namun belum mampu memberikan } \\
\text { kesimpulan. }\end{array}$ & 2 \\
\hline & $\begin{array}{l}\text { Belum mampu menyelesaikan langkah-langkah } \\
\text { penyelesaian soal dan memberikan kesimpulan dengan } \\
\text { tepat }\end{array}$ & 1 \\
\hline & Tidak mampu melakukan proses mengevaluasi sama sekali & 0 \\
\hline \multirow[t]{5}{*}{ M engkreasi } & $\begin{array}{l}\text { Mampu merancang dan memadukan informasi dari proses } \\
\text { menganalisis dan mengevaluasi dengan tepat }\end{array}$ & 4 \\
\hline & $\begin{array}{l}\text { M ampu merancang dan memadukan informasi dari proses } \\
\text { menganalisis dan mengevaluasi dengan hampir tepat atau } \\
\text { masih ada sedikit kesalahan dalam menulis jawaban }\end{array}$ & 3 \\
\hline & $\begin{array}{l}\text { Mampu merancang namun belum mampu memadukan } \\
\text { informasi dari proses menganalisis dan mengevaluasi } \\
\text { sehingga terdapat kesalahan dalam menulis jawaban }\end{array}$ & 2 \\
\hline & $\begin{array}{l}\text { Belum mampu merancang dan memadukan informasi dari } \\
\text { proses menganalisis dan mengevaluasi namun rancangan } \\
\text { jawaban sudah hampir mengarah ke cara yang tepat }\end{array}$ & 1 \\
\hline & Tidak mampu melakukan proses mengkreasi sama sekali & 0 \\
\hline
\end{tabular}

\section{METODE PENELITIAN}

Penelitian ini merupakan penelitian deskriptif. Dalam penelitian ini, peneliti akan mendeskripsikan keterampilan berpikir tingkat tinggi siswa kelas XII dalam menyelesaikan soal UN fisika SMA pada materi medan magnet di SMA Muhammadiyah 3 Jember. Variabel dalam penelitian ini adalah kemampuan berpikir tingkat tinggi siswa kelas XII.

Keterampilan berpikir tingkat tinggi siswa pada penelitian ini adalah keterampilan siswa dalam menganalisis, mengevaluasi, dan mengkreasikan. Keterampilan tersebut dinilai berdasarkan skor yang diperoleh siswa melalui soal tes berpikir tingkat tinggi. Subjek dalam penelitian ini adalah kelas XII SM A M uhammadiyah 3 Jember yang berjumlah 192 siswa.

Prosedur dalam penelitian ini terdiri atas tiga tahapan, yaitu tahap persiapan, tahap pelaksanaan kegiatan, dan tahap pengumpulan data, sebagaimana tercantum dalam alur di bawah: 


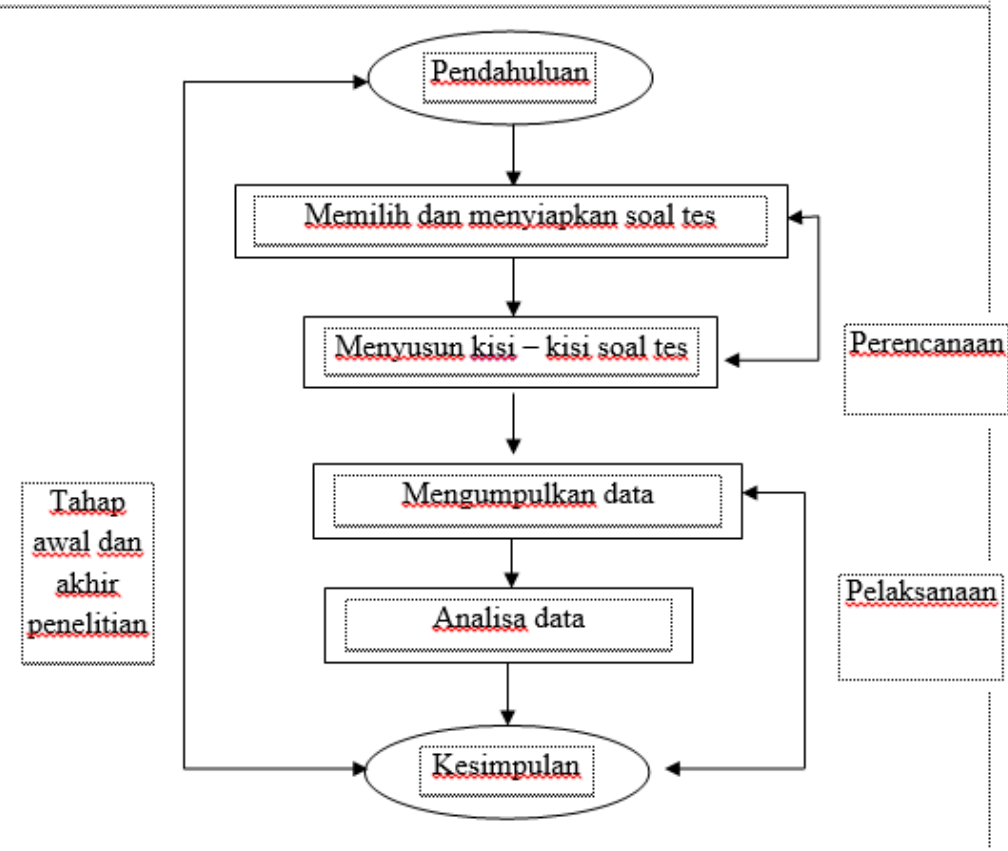

Gambar 1: Alur Tahapan Penelitian

Kegiatan pendahuluan, bertujuan untuk menentukan daerah penelitian, membuat surat izin penelitian, dan berkoordinasi dengan guru fisika penelitian untuk menentukan jadwal pelaksanaan penelitian. Kegiatan memilih dan menyiapkan soal tes diawali dengan memilih soal Ujian Nasional yang telah ada dalam jangka waktu 10 tahun kebelakang dari tahun 2007-2017. Soal Ujian Nasional (UN) digunakan sebagai tes di klasifikasikan berdasarkan SKL dan bentuk soal yang telah ada sebelumnya. Soal yang mempunyai SKL yang tidak sama dan bentuk soal yang tidak sama akan digunakan sebagai soal tes sebagai tujuan agar soal yang digunakan mempunyai variasi yang berbeda pada materi medan magnet. Setalah dipilih, soal Ujian Nasional (UN) yang akan digunakan dimodifikasi berbentuk soal uraian untuk dapat dikerjakan sesuai indikator keterampilan berpikir tingkat tinggi. Soal tes tersebut disajikan dalam lembar soal yang nanti digunakan siswa sebagai soal tes. Kegiatan menyusun kisi-kisi soal tes dilakukan dengan membuat langkah penyelesaian sesuai indikator keterampilan berpikir tingkat tinggi. Kegiatan mengumpulkan data dilakukan dengan memberikan tes soal Ujian Nasional (UN) materi medan magnet sebanyak 5 butir soal pada subjek penelitian. Pengumpulan data bertujuan untuk mengetahui keterampilan berpikir tingkat tinggi siswa dalam menyelesaikan soal Ujian Nasional (UN) materi medan magnet. Kegiatan terakhir adalah analisis data, dilakukan dengan menganalisis hasil jawaban siswa berdasarkan pedoman penyelesaikan pada indikator keterampilan 
berpikir tingkat tinggi. Analisis data ini bertujan untuk mendeskripsikan keterampilan berpikit tingkat tinggi siswa dalam menyelesaikan soal Ujian Nasional (UN) materi medan magnet.

Tes yang diberikan merupakan tes tertulis bentuk uraian. Tes ini terdiri dari tiga buah soal yang harus dijawab siswa mengenai kompetensi dasar dan indikator kemampuan berpikir tingkat tinggi siswa terkait materi rumus-rumus medan magnet. Tes ini dikerjakan siswa secara individu.

Setelah tes dilaksanakan, maka didapatlah skor masing-masing siswa. Skor tersebut dijumlahkan Ialu dianalisis. Langkah untuk menganalsisis data hasil tes tertulis adalah menentukan nilai tes siswa dan menentukan kategori berpikir tingkat tinggi siswa.

Tabel 3

Kriteria Higher Order Thinkings Skill

\begin{tabular}{cc} 
Tingkat Higher Order Thinkings Skill & Kriteria \\
$X \leq 12$ & Sangat Rendah \\
\hline $12<X \leq 20$ & Rendah \\
\hline $20<X \leq 28$ & Sedang \\
\hline $28<X \leq 36$ & Tinggi \\
\hline $36<X$ & Sangat Tinggi \\
\hline
\end{tabular}

Sumber: Shiddiq, A.S., M aryani, M ., dan Susanti, V.H (2014)

\section{PEMBAHASAN}

Penelitian ini adalah penelitian deskriptif kuantitatif untuk menjelaskan fenomena yang ada dengan menggunakan angka-angka untuk menggambarkan karakteristik individu atau kelompok (subjek penelitian). Tujuan penelitian ini adalah untuk mendeskripsikan keterampilan berpikir tingkat tinggi siswa dalam menyelesaikan soal Ujian Nasional (UN) Fisika SMA pada materi Medan Magnet. Tahapan keterampilan berpikir tingkat tinggi ada tiga, yaitu: (a) menganalisis; (b) mengevaluasi; dan (c) mengkreasikan. M ateri medan magnet dipilih sebagai materi penelitian karena materi medan magnet telah diajarkan kepada siswa SMA M uhammadiyah 3 Jember di semester genap dan menjadi salah satu materi yang menjadi SKL Ujian Nasional (UN) siswa kelas XII SMA serta masih sedikitnya penelitian menggunakan materi medan magnet. Penelitian ini menggunakan instrument tes berbentuk uraian dengan 5 butir soal. Soal yang digunakan untuk 
tes keterampilan berpikir tingkat tinggi merupakan soal Ujian Nasional (UN) tahun sebelumnya. Penelitian ini dilakukan pada kelas XII MIPA di SMA M uhammadityah 3 Jember sebanyak 192 siswa.

Penelitian ini dilaksanakan pada tanggal 26-28 Oktober 2018 di SMA M uhammadiyah 3 Jember. Penelitian dilaksanakan sebanyak 6 pertemuan (12 jam pelajaran) dengan satu pertemuan untuk kegiatan tes keterampilan berpikir tingkat tinggi tiap kelasnya. Tes dikerjakan oleh siswa secara individu. Penskoran yang dilakukan adalah sesuai dengan rubrik penskoran yang telah dibuat. Masingmasing indikator terdiri atas satu deskriptor. Skor maksimal per deskriptor adalah empat dan skor minimumnya adalah nol. Soal terdiri dari lima soal tes UN Fisika SM A rentang waktu 10 tahun yaitu tahun 2007-2017 yang dimodifikasi menjadi tes soal uraian. Total skor maksimal seluruh soal adalah 20 setiap soal mempunyai bobot skor 4.

Setelah semua jawaban siswa diperiksa dan diberikan skor sesuai rubrik penskoran, maka langkah selanjutnya adalah menghitung presentase perolehan skor pada setiap tahapan keterampilan berpikir tingkat tinggi dengan cara skor total yang diperoleh siswa dalam satu kelas dibagi banyaknya siswa dikalikan $100 \%$. Setelah diperoleh presentase dari setiap tahapan, maka skor presentase tersebut di rata-rata untuk selanjutnya dikelompokkan ke dalam lima kategori keterampilan berpikir tingkat tinggi yang dapat dilihat pada tabel berikut:

Tabel 4.

Presentase Keterampilan Berpikir Tingkat Tinggi Siswa dalam M enyelesaikan Soal UN Fisika SM A M ateri M edan Magnet

Tiap Kelas XII MIPA SM A M uhammadiyah 3 Jember

\begin{tabular}{lcc} 
Kelas & $\begin{array}{c}\text { Presentase Kemampuan } \\
\text { Berpikir Tingkat Tinggi }\end{array}$ & Kriteria \\
\hline XII MIPA 1 & $17.73 \%$, & Sedang \\
\hline XII M IPA 2 & $20.75 \%$ & Sedang \\
\hline XII MIPA 3 & $29.25 \%$ & Tinggi \\
\hline XII M IPA 4 & $25.44 \%$ & Sedang \\
\hline XII MIPA 5 & $23.70 \%$ & Sedang \\
\hline XII MIPA 6 & $23.08 \%$ & Sedang \\
\hline
\end{tabular}

Pada tabel 4 menunjukkan perbandingan keterampilan berpikir tingkat tinggi siswa kelas XII MIPA SM A M uhammadiyah 3 Jember. Kelas yang mendapatkan kriteria keterampilan berpikir tingkat tinggi tertinggi yaitu XII MIPA 3 dengan presentase sebesar $29.25 \%$ dengan predikat tinggi, sedangkan kelas XII MIPA 1 
mendapat presentase sebesar $17.73 \%$ dengan predikat sedang, pada kelas XII MIPA 2 mendapat presentase sebesar $20.75 \%$ dengan predikat sedang, pada kelas XII M IPA 4 mendapat presentase sebesar $25.44 \%$ dengan predikat sedang, pada kelas XII MIPA 5 mendapat presentase sebesar $23.70 \%$ dengan predikat sedang, dan kelas XII MIPA 6 mendapat presentase sebesar $23.08 \%$ dengan presentase sedang. Perbandingan keterampilan berpikir tingkat tinggi dalam menyelesaikan soal Ujian Nasional (UN) Fisika SMA materi Medan Magnet siswa kelas XII SMA M uhammadiyah $3 \mathrm{~J}$ ember dapat dilihat pada gambar 1.

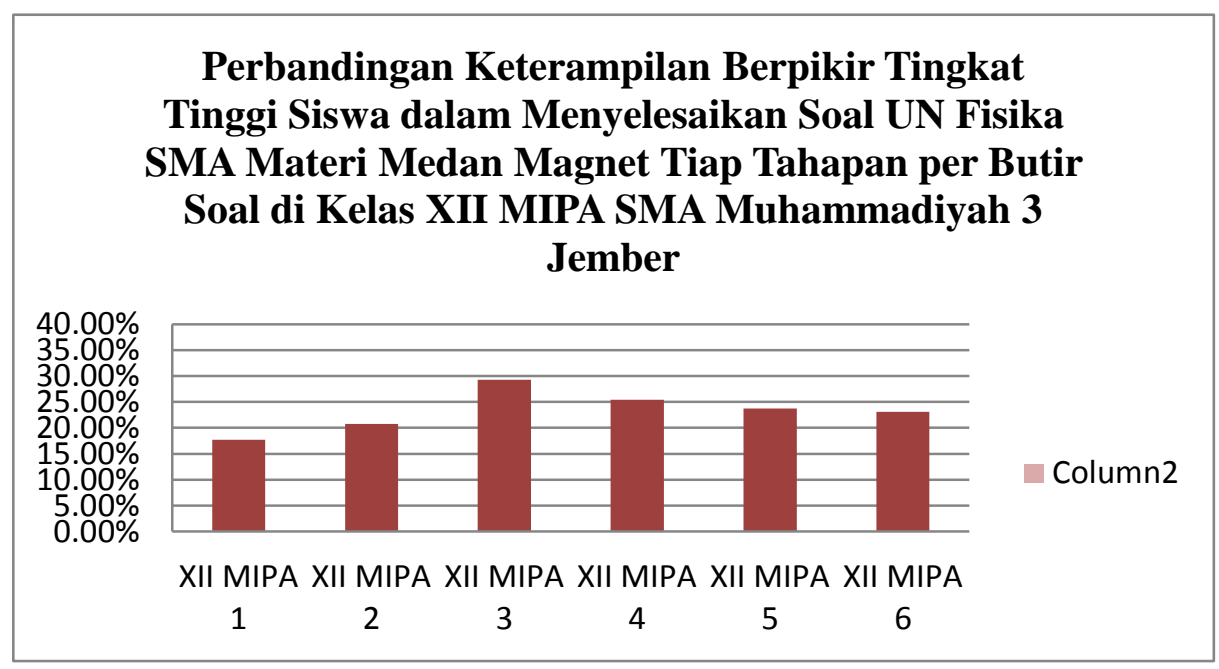

Gambar 2: Perbandingan Keterampilan Berpikir Tingkat Tinggi Siswa dalam M enyelesaikan Soal U N Fisika SM A M ateri M edan Magnet Tiap Tahapan per Butir Soal di Kelas XII MIPA SM A M uhammadiyah 3Jember.

Berdasarkan pada penelitian relevan terdahulu, dalam penelitian ini dibuat desain Tujuan penelitian ini adalah untuk mendeskripsikan keterampilan berpikir tingkat tinggi siswa dalam menyelesaikan soal Ujian Nasional (UN) Fisika SMA pada materi Medan Magnet. Tahapan keterampilan berpikir tingkat tinggi ada tiga, yaitu : a) menganalisis, b) mengevaluasi, dan c) mengkreasikan. Materi medan magnet dipilih sebagai materi penelitian karena materi medan magnet telah diajarkan kepada siswa SM A Muhammadiyah 3 Jember di semester genap dan menjadi salah satu materi yang menjadi SKL Ujian Nasional (UN) siswa kelas XII SMA serta masih sedikitnya penelitian menggunakan materi medan magnet. Penelitian ini menggunakan instrument tes berbentuk uraian dengan 5 butir soal. Soal yang digunakan untuk tes keterampilan berpikir tingkat tinggi merupakan 
soal Ujian Nasional (UN) tahun sebelumnya. Penelitian ini dilakukan pada kelas XII MIPA di SM A M uhammadityah 3Jember sebanyak 192 siswa.

Tahapan pertama pada keterampilan berpikir tingkat tinggi adalah tahapan menganalisis. Tahap menganalisis siswa dituntut untuk mampu menguraikan informasi (diketahui dan dijawab) serta menguraikan langkah-langkah penyelesaian soal secara lengkap dan benar. Keterampilan berpikir tingkat di kelas XII MIPA 1 menunjukkan banyak siswa yang mendapatkan skor 4 yaitu pada soal pertama sebanyak $50 \%$, soal kedua sebanyak $37.5 \%$, soal ketiga sebanyak $40.62 \%$, soal keempat sebanyak $18.75 \%$, soal kelima sebanyak $6.25 \%$. Keterampilan berpikir tingkat di kelas XII MIPA 2 menunjukkan banyak siswa yang mendapatkan skor 3 yaitu pada soal pertama sebanyak $48.38 \%$, soal kedua sebanyak $74.19 \%$, soal ketiga sebanyak $22.58 \%$, soal keempat sebanyak $32.25 \%$, soal kelima sebanyak $12.90 \%$. Keterampilan berpikir tingkat di kelas XII MIPA 3 menunjukkan banyak siswa yang mendapatkan skor 4 yaitu pada soal pertama sebanyak $61.29 \%$, soal kedua sebanyak $51.61 \%$, soal ketiga sebanyak $77.42 \%$, soal keempat sebanyak $74.19 \%$, soal kelima sebanyak $00.00 \%$. Keterampilan berpikir tingkat di kelas XII MIPA 4 menunjukkan banyak siswa yang mendapatkan skor 3 yaitu pada soal pertama sebanyak $88.23 \%$, soal kedua sebanyak $79.41 \%$, soal ketiga sebanyak $20.58 \%$, soal keempat sebanyak $17.64 \%$, soal kelima sebanyak $52.94 \%$. Keterampilan berpikir tingkat di kelas XII MIPA 5 menunjukkan banyak siswa yang mendapatkan skor 3 yaitu pada soal pertama sebanyak $100 \%$, soal kedua sebanyak $76.47 \%$, soal ketiga sebanyak $26.47 \%$, soal keempat sebanyak $32.35 \%$, soal kelima sebanyak $8.82 \%$. Keterampilan berpikir tingkat di kelas XII MIPA 6 menunjukkan banyak siswa yang mendapatkan skor 4 yaitu pada soal pertama sebanyak $9.37 \%$, soal kedua sebanyak $15.62 \%$, soal ketiga sebanyak $84.37 \%$, soal keempat sebanyak $46.87 \%$, soal kelima sebanyak $00.00 \%$. Jadi, dapat disimpulkan bahwa siswa kelas XII MIPA SM A Muhammadiyah 3 Jember pada tahap menganalisis mampu menguraikan informasi (diketahui dan ditanya) serta langkah-langkah penyelesaian soal secara tidak kengkap tetapi dengan simbol yang benar.

Tahapan ketiga pada keterampilan berpikir tingkat tinggi adalah tahapan mengkreasikan. Tahap mengkreasikan siswa dituntut untuk mampu memeriksa kembali jawaban dengan data yang diketahui dengan benar. Keterampilan berpikir tingkat di kelas XII MIPA 1 menunjukkan banyak siswa yang mendapatkan skor 0 yaitu pada soal pertama sebanyak $31.25 \%$, soal kedua sebanyak $50 \%$, soal ketiga sebanyak $65.62 \%$, soal keempat sebanyak $62.5 \%$, soal kelima sebanyak $62.5 \%$. Keterampilan berpikir tingkat di kelas XII MIPA 2 menunjukkan banyak siswa yang mendapatkan skor 0 yaitu pada soal pertama sebanyak $18.75 \%$, soal kedua 
sebanyak $37.5 \%$, soal ketiga sebanyak $43.75 \%$, soal keempat sebanyak $53.12 \%$, soal kelima sebanyak $75 \%$. Keterampilan berpikir tingkat di kelas XII MIPA 3 menunjukkan banyak siswa yang mendapatkan skor 3 yaitu pada soal pertama sebanyak $22.58 \%$, soal kedua sebanyak $9.67 \%$, soal ketiga sebanyak $16.13 \%$, soal keempat sebanyak $19.02 \%$, soal kelima sebanyak $45.16 \%$. Keterampilan berpikir tingkat di kelas XII MIPA 4 menunjukkan banyak siswa yang mendapatkan skor 3 yaitu pada soal pertama sebanyak $55.88 \%$, soal kedua sebanyak $58.82 \%$, soal ketiga sebanyak $14.70 \%$, soal keempat sebanyak $32.35 \%$, soal kelima sebanyak $73.52 \%$. Keterampilan berpikir tingkat di kelas XII MIPA 5 menunjukkan banyak siswa yang mendapatkan skor 0 yaitu pada soal pertama sebanyak $2.94 \%$, soal kedua sebanyak $23.52 \%$, soal ketiga sebanyak $44.11 \%$, soal keempat sebanyak $50 \%$, soal kelima sebanyak 73.52\%. Keterampilan berpikir tingkat di kelas XII MIPA 6 menunjukkan banyak siswa yang mendapatkan skor 3 yaitu pada soal pertama sebanyak $71.87 \%$, soal kedua sebanyak $46.87 \%$, soal ketiga sebanyak $40.62 \%$, soal keempat sebanyak $15.62 \%$, soal kelima sebanyak $00.00 \%$. Jadi, dapat simpulkan bahwa siswa kelas XII MIPA di SMA Muhammadiyah 3 Jember pada tahap mengkreasikan masih kurang mampu memeriksa kembali jawaban dengan data yang diketahui walaupun terdapat keterangan lain.

Berdasarkan hasil penelitian, secara keseluruhan diperoleh presentase rata-rata keterampilan berpikir tingkat tinggi siswa dalam menyelesaikan soal UN fisika materi medan magnet di kelas XII MIPA 1 pada tahapan menganalisis sebesar $24.56 \%$. Skor terbanyak yang diperoleh pada tahap menganalisis mencapai skor 4. $\mathrm{Hal}$ ini berarti keterampilan siswa dalam menganalisis soal sangat tinggi dimana siswa mampu menuliskan diketahui, ditanya, dan langkah-langkah penyelesaian dengan tepat. Berdasarkan wawancara siswa mengenai tahapan menganalisis, siswa mengerti dengan tahapan menganalisis sehingga dapat mempermudah untuk mengidentifikasi apa yang diketahui dan ditanya serta menyusun langkah-langkah penyelesaian masalah dengan baik. Sehingga pada tahapan menganalisis siswa kelas XII MIPA 1 mampu menuliskan data yang diketahui dan ditanya serta menguraikan langkah-langkah penyelesaian masalah dari soal.

Presentase rata-rata tahapan mengevaluasi di kelas XII MIPA 1 sebesar 18.12\% dengan skor terbanyak yang diperoleh siswa pada tahapan mengevaluasi mencapai skor 3. Hal ini berarti keterampilan siswa dalam mengevaluasi soal tinggi Walaupun pada tahapan mengevalusi siswa tidak memberikan langkah-langkah untuk penyelesaian soal, tetapi siswa dapat melaksanakan rencana sesuai rumus dan perhitungan yang mereka buat tidak secara langsung tertuang dengan tertulis 
di tahap mengevaluasi untuk selanjutnya menarik kesimpulan. Sebagian besar siswa mampu menyelesaikan langkah-langkah penyelesaian soal dengan baik dan benar namun terdapat kesalahan dalam memberikan kesimpulan. Wawancara dengan siswa memberikan informasi bahwa dengan keterampilan mengevaluasi bahwa siswa dengan keterampilan tinggi dan sedang mengerti dengan rumus yang digunakan dan mampu memberikan kesimpulan dengan tepat, tetapi siswa dengen keterampilan rendah memberikan informasi bahwa masih kurang paham dengan rumus yang digunakan sehingga bisa atau tidaknya mengerjakan soal tergentung pada permasalahan yang diberikan. Sehingga dapat diketahui bahwa siswa kelas XII MIPA 1 pada tahapan mengevaluasi mampu melaksanakan perhitungan permasalahan sesuai dengan langkah-langkah penyelesaian yang telah dibuat namun masih terdapat kesalahan dalam memberikan kesimpulan.

Presentase rata-rata tahapan mengkreasikan di kelas XII MIPA 1 sebesar $10.50 \%$ merupakan presentase terendah dibandingkan tahapan lain. Skor terbanyak dicapai pada tahapan mengkreasikan adalah skor 0 . Hal ini menunjukkan bahwa keterampilan mengkreasikan siswa sangat rendah, karena hampir seluruh siswa tidak memberikan jawaban pada tahapan mengkreasikan. Berdasarkan wawancara dengan siswa kelas XII MIPA 1 diperoleh bahwa siswa mengerti dengan tahapan mengkreasikan, dengan tahapan mengkreasikan siswa dapat merancang dan memadukan informasi atau data dari tahapan menganalisis dan mengevalusi sehingga siswa juga dapat mengkoreksi kembali apakah rumus, jawaba, dan perhitungan yang dikerjakan benar. Tetapi pada kenyataannya siswa tidak melakukan tahapan mengkreasikan hal ini dibuktikan pada kolom mengkreasikan tidak diberi keterangan sama sekali. Sehingga dapat diketahui bahwa siswa kelas XII MIPA 1 pada tahapan mengkreasikan tidak terbiasa menggunakan langkahlangkah yang runtut dalam mengkreasikan soal walaupun penting untuk mengetahui penyelesaian soal benar atau tidak.

Berdasarkan hasil penelitian, secara keseluruhan diperoleh presentase rata-rata keterampilan berpikir tingkat tinggi siswa dalam menyelesaikan soal UN fisika materi medan magnet di kelas XII MIPA 2 pada tahapan menganalisis sebesar $24.45 \%$. Skor terbanyak yang diperoleh pada tahap menganalisis mencapai skor 3. $\mathrm{Hal}$ ini berarti keterampilan siswa dalam menganalisis soal tinggi dimana siswa mampu menuliskan diketahui, ditanya, namun terdapat kesalahan dalam memformulasikan langkah-langkah penyelesaian soal. Berdasarkan wawancara siswa mengenai tahapan menganalisis, siswa mengerti dengan tahapan menganalisis sehingga dapat mempermudah untuk mengidentifikasi apa yang diketahui dan ditanya namun terdapat kesulitan ketika harus memformulasikan 
atau menyusun langkah-langkah penyelesaian masalah. Sehingga pada tahapan menganalisis siswa kelas XII MIPA 2 mampu menuliskan data yang diketahui ditanya tetapi kurang mampu menguraikan langkah-langkah penyelesaian masalah dari soal.

Presentase rata-rata tahapan mengevaluasi di kelas XII MIPA 2 sebesar $21.56 \%$ dengan skor terbanyak yang diperoleh siswa pada tahapan mengevaluasi mencapai skor 3. Hal ini berarti keterampilan siswa dalam mengevaluasi soal tinggi Walaupun pada tahapan mengevalusi siswa tidak memberikan langkah-langkah untuk penyelesaian soal, tetapi siswa dapat melaksanakan rencana sesuai rumus dan perhitungan yang mereka buat tidak secara langsung tertuang dengan tertulis di tahap mengevaluasi untuk selanjutnya menarik kesimpulan. Sebagian besar siswa mampu menyelesaikan langkah-langkah penyelesaian soal dengan baik dan benar namun terdapat kesalahan dalam memberikan kesimpulan. Wawancara dengan siswa memberikan informasi bahwa dengan keterampilan mengevaluasi bahwa siswa dengan keterampilan tinggi dan sedang mengerti dengan rumus yang digunakan dan mampu memberikan kesimpulan dengan tepat, tetapi siswa dengen keterampilan rendah memberikan informasi bahwa masih kurang paham dengan rumus yang digunakan sehingga bisa atau tidaknya mengerjakan soal tergentung pada permasalahan yang diberikan. Sehingga dapat diketahui bahwa siswa kelas XII MIPA 2 pada tahapan mengevaluasi mampu melaksanakan perhitungan permasalahan sesuai dengan langkah-langkah penyelesaian yang telah dibuat namun masih terdapat kesalahan dalam memberikan kesimpulan.

Presentase rata-rata tahapan mengkreasikan di kelas XII MIPA 2 sebesar $16.25 \%$ merupakan presentase terendah dibandingkan tahapan lain. Skor terbanyak dicapai pada tahapan mengkreasikan adalah skor 0 . Hal ini menunjukkan bahwa keterampilan mengkreasikan siswa sangat rendah, karena hampir seluruh siswa tidak memberikan jawaban pada tahapan mengkreasikan. Berdasarkan wawancara dengan siswa kelas XII MIPA 2 diperoleh bahwa siswa mengerti dengan tahapan mengkreasikan, dengan tahapan mengkreasikan siswa dapat merancang dan memadukan informasi atau data dari tahapan menganalisis dan mengevalusi sehingga siswa juga dapat mengkoreksi kembali apakah rumus, jawaba, dan perhitungan yang dikerjakan benar. Tetapi pada kenyataannya siswa tidak melakukan tahapan mengkreasikan hal ini dibuktikan pada kolom mengkreasikan tidak diberi keterangan sama sekali. Sehingga dapat diketahui bahwa siswa kelas XII MIPA 2 pada tahapan mengkreasikan tidak terbiasa menggunakan langkah- 
langkah yang runtut dalam mengkreasikan soal walaupun penting untuk mengetahui penyelesaian soal benar atau tidak.

Berdasarkan hasil penelitian, secara keseluruhan diperoleh presentase rata-rata keterampilan berpikir tingkat tinggi siswa dalam menyelesaikan soal UN fisika materi medan magnet di kelas XII MIPA 3 pada tahapan menganalisis sebesar $32.03 \%$. Skor terbanyak yang diperoleh pada tahap menganalisis mencapai skor 4 . $\mathrm{Hal}$ ini berarti keterampilan siswa dalam menganalisis soal sangat tinggi dimana siswa mampu menuliskan diketahui, ditanya, dan memformulasikan langkahlangkah penyelesaian soal dengan tepat. Berdasarkan wawancara siswa mengenai tahapan menganalisis, siswa mengerti dengan tahapan menganalisis sehingga dapat mempermudah untuk mengidentifikasi apa yang diketahui, ditanya, dan memformulasikan atau menyusun langkah-langkah penyelesaian masalah.

Presentase rata-rata tahapan mengevaluasi di kelas XII MIPA 3 sebesar $30.19 \%$ dengan skor terbanyak yang diperoleh siswa pada tahapan mengevaluasi mencapai skor 4. Hal ini berarti keterampilan siswa dalam mengevaluasi soal sangat tinggi dimana pada tahapan mengevalusi siswa mampu memberikan langkah-langkah untuk penyelesaian soal dan dapat melaksanakan rencana sesuai rumus dan perhitungan yang mereka buat secara langsung tertuang dengan tertulis di tahap mengevaluasi untuk selanjutnya menarik kesimpulan. Sebagian besar siswa mampu menyelesaikan langkah-langkah penyelesaian soal serta menarik kesimpulan dengan tepat. W awancara dengan siswa memberikan informasi bahwa dengan keterampilan mengevaluasi bahwa siswa dengan keterampilan tinggi dan sedang mengerti dengan rumus yang digunakan dan mampu memberikan kesimpulan dengan tepat, tetapi siswa dengen keterampilan rendah memberikan informasi bahwa masih kurang paham dengan rumus yang digunakan sehingga bisa atau tidaknya mengerjakan soal tergentung pada permasalahan yang diberikan. Sehingga dapat diketahui bahwa siswa kelas XII MIPA 3 pada tahapan mengevaluasi mampu melaksanakan perhitungan permasalahan sesuai dengan langkah-langkah penyelesaian yang telah dibuat serta menarik kesimpulan dengan tepat.

Presentase rata-rata tahapan mengkreasikan di kelas XII MIPA 3 sebesar $25.54 \%$ merupakan presentase terendah dibandingkan tahapan lain. Skor terbanyak dicapai pada tahapan mengkreasikan adalah skor 4 . Hal ini menunjukkan bahwa keterampilan mengkreasikan siswa sangat tinggi, dimana siswa dapat menyelesaikan tahpan mengkreasikan dengan merancang dan memadukan penyelesaian tahapan menganalisis dan mengevaluasi dengan tepat. Berdasarkan 
wawancara dengan siswa kelas XII MIPA 3 diperoleh bahwa siswa mengerti dengan tahapan mengkreasikan, dengan tahapan mengkreasikan siswa dapat merancang dan memadukan informasi atau data dari tahapan menganalisis dan mengevalusi sehingga siswa juga dapat mengkoreksi kembali apakah rumus, jawaban, dan perhitungan yang dikerjakan benar.

Berdasarkan hasil penelitian, secara keseluruhan diperoleh presentase rata-rata keterampilan berpikir tingkat tinggi siswa dalam menyelesaikan soal UN fisika materi medan magnet di kelas XII MIPA 4 pada tahapan menganalisis sebesar $30.92 \%$. Skor terbanyak yang diperoleh pada tahap menganalisis mencapai skor 3 . $\mathrm{Hal}$ ini berarti keterampilan siswa dalam menganalisis soal tinggi dimana siswa mampu menuliskan diketahui, ditanya, namun terdapat kesalahan dalam memformulasikan langkah-langkah penyelesaian soal. Berdasarkan wawancara siswa mengenai tahapan menganalisis, siswa mengerti dengan tahapan menganalisis sehingga dapat mempermudah untuk mengidentifikasi apa yang diketahui dan ditanya namun terdapat kesulitan ketika harus memformulasikan atau menyusun langkah-langkah penyelesaian masalah. Sehingga pada tahapan menganalisis siswa kelas XII MIPA 4 mampu menuliskan data yang diketahui ditanya tetapi kurang mampu menguraikan langkah-langkah penyelesaian masalah dari soal.

Presentase rata-rata tahapan mengevaluasi di kelas XII MIPA 4 sebesar 24.36\% dengan skor terbanyak yang diperoleh siswa pada tahapan mengevaluasi mencapai skor 2. Hal ini berarti keterampilan siswa dalam mengevaluasi soal sedang, dimana siswa pada tahapan mengevalusi siswa tidak memberikan langkah-langkah untuk penyelesaian soal, tetapi siswa dapat melaksanakan rencana sesuai rumus dan perhitungan yang mereka buat tidak secara langsung tertuang dengan tertulis di tahap mengevaluasi untuk selanjutnya menarik kesimpulan. Sebagian besar siswa mampu menyelesaikan langkah-langkah penyelesaian soal dengan baik dan benar namun belum mampu untuk memberikan kesimpulan. Wawancara dengan siswa memberikan informasi bahwa dengan keterampilan mengevaluasi bahwa siswa dengan keterampilan tinggi dan sedang mengerti dengan rumus yang digunakan dan mampu memberikan kesimpulan dengan tepat, tetapi siswa dengan keterampilan rendah memberikan informasi bahwa masih kurang paham dengan rumus yang digunakan sehingga bisa atau tidaknya mengerjakan soal tergentung pada permasalahan yang diberikan. Sehingga dapat diketahui bahwa siswa kelas XII MIPA 4 pada tahapan mengevaluasi mampu melaksanakan perhitungan 
permasalahan sesuai dengan langkah-langkah penyelesaian yang telah dibuat namun belum dapat memberikan kesimpulan.

Presentase rata-rata tahapan mengkreasikan di kelas XII MIPA 4 sebesar 21.02\% merupakan presentase terendah dibandingkan tahapan lain. Skor terbanyak dicapai pada tahapan mengkreasikan adalah skor 2. Hal ini menunjukkan bahwa keterampilan mengkreasikan siswa sedang dimana siswa mampu merancang penyelesaikan namun belum mampu memadukan informasi dari tahapan menganalisis dan tahapan mengevaluasi sehingga kebanyakan siswa masih salah dalam menulis jawaban. Berdasarkan wawancara dengan siswa kelas XII MIPA 4 diperoleh bahwa siswa mengerti dengan tahapan mengkreasikan, dengan tahapan mengkreasikan siswa dapat merancang dan memadukan informasi atau data dari tahapan menganalisis dan mengevalusi sehingga siswa juga dapat mengkoreksi kembali apakah rumus, jawaban, dan perhitungan yang dikerjakan benar. Tetapi pada kenyataannya siswa belum mampu melakukan tahapan mengkreasikan secara tepat. Sehingga dapat diketahui bahwa siswa kelas XII MIPA 4 pada tahapan mengkreasikan tidak terbiasa menggunakan langkah-langkah yang runtut dalam mengkreasikan soal walaupun penting untuk mengetahui penyelesaian soal benar atau tidak.

Berdasarkan hasil penelitian, secara keseluruhan diperoleh presentase rata-rata keterampilan berpikir tingkat tinggi siswa dalam menyelesaikan soal UN fisika materi medan magnet di kelas XII MIPA 5 pada tahapan menganalisis sebesar $26.45 \%$. Skor terbanyak yang diperoleh pada tahap menganalisis mencapai skor 3 . $\mathrm{Hal}$ ini berarti keterampilan siswa dalam menganalisis soal tinggi dimana siswa mampu menuliskan diketahui, ditanya, namun terdapat kesalahan dalam memformulasikan langkah-langkah penyelesaian soal. Berdasarkan wawancara siswa mengenai tahapan menganalisis, siswa mengerti dengan tahapan menganalisis sehingga dapat mempermudah untuk mengidentifikasi apa yang diketahui dan ditanya namun terdapat kesulitan ketika harus memformulasikan atau menyusun langkah-langkah penyelesaian masalah. Sehingga pada tahapan menganalisis siswa kelas XII MIPA 5 mampu menuliskan data yang diketahui ditanya tetapi kurang mampu menguraikan langkah-langkah penyelesaian masalah dari soal.

Presentase rata-rata tahapan mengevaluasi di kelas XII MIPA 5 sebesar 26.35\% dengan skor terbanyak yang diperoleh siswa pada tahapan mengevaluasi mencapai skor 2. Hal ini berarti keterampilan siswa dalam mengevaluasi soal sedang, dimana siswa pada tahapan mengevalusi siswa tidak memberikan langkah-langkah untuk 
penyelesaian soal, tetapi siswa dapat melaksanakan rencana sesuai rumus dan perhitungan yang mereka buat tidak secara langsung tertuang dengan tertulis di tahap mengevaluasi untuk selanjutnya menarik kesimpulan. Sebagian besar siswa mampu menyelesaikan langkah-langkah penyelesaian soal dengan baik dan benar namun belum mampu untuk memberikan kesimpulan. Wawancara dengan siswa memberikan informasi bahwa dengan keterampilan mengevaluasi bahwa siswa dengan keterampilan tinggi dan sedang mengerti dengan rumus yang digunakan dan mampu memberikan kesimpulan dengan tepat, tetapi siswa dengan keterampilan rendah memberikan informasi bahwa masih kurang paham dengan rumus yang digunakan sehingga bisa atau tidaknya mengerjakan soal tergentung pada permasalahan yang diberikan. Sehingga dapat diketahui bahwa siswa kelas XII MIPA 5 pada tahapan mengevaluasi mampu melaksanakan perhitungan permasalahan sesuai dengan langkah-langkah penyelesaian yang telah dibuat namun belum dapat memberikan kesimpulan.

Presentase rata-rata tahapan mengkreasikan di kelas XII MIPA 5 sebesar 18.29\% merupakan presentase terendah dibandingkan tahapan lain. Skor terbanyak dicapai pada tahapan mengkreasikan adalah skor 0 . Hal ini menunjukkan bahwa keterampilan mengkreasikan siswa sangat rendah dimana sebagian besar siswa belum mampu merancang dan memadukan informasi dari tahapan menganalisis dan tahapan mengevaluasi terlihat dengan kolom jawaban tahapan mengkreasikan banyak yang kosong. Berdasarkan wawancara dengan siswa kelas XII MIPA 5 diperoleh bahwa siswa mengerti dengan tahapan mengkreasikan, dengan tahapan mengkreasikan siswa dapat merancang dan memadukan informasi atau data dari tahapan menganalisis dan mengevalusi sehingga siswa juga dapat mengkoreksi kembali apakah rumus, jawaban, dan perhitungan yang dikerjakan benar. Tetapi pada kenyataannya sebagian siswa belum mampu melalukan tahapan mengkreasikan. Sehingga dapat diketahui bahwa siswa kelas XII MIPA 5 pada tahapan mengkreasikan tidak terbiasa menggunakan langkah-langkah yang runtut dalam mengkreasikan soal walaupun penting untuk mengetahui penyelesaian soal benar atau tidak.

Berdasarkan hasil penelitian, secara keseluruhan diperoleh presentase rata-rata keterampilan berpikir tingkat tinggi siswa dalam menyelesaikan soal UN fisika materi medan magnet di kelas XII MIPA 6 pada tahapan menganalisis sebesar $27.25 \%$. Skor terbanyak yang diperoleh pada tahap menganalisis mencapai skor 3. $\mathrm{Hal}$ ini berarti keterampilan siswa dalam menganalisis soal tinggi dimana siswa mampu menuliskan diketahui, ditanya, namun terdapat kesalahan dalam 
memformulasikan langkah-langkah penyelesaian soal. Berdasarkan wawancara siswa mengenai tahapan menganalisis, siswa mengerti dengan tahapan menganalisis sehingga dapat mempermudah untuk mengidentifikasi apa yang diketahui dan ditanya namun terdapat kesulitan ketika harus memformulasikan atau menyusun langkah-langkah penyelesaian masalah. Sehingga pada tahapan menganalisis siswa kelas XII MIPA 6 mampu menuliskan data yang diketahui ditanya tetapi kurang mampu menguraikan langkah-langkah penyelesaian masalah dari soal.

Presentase rata-rata tahapan mengevaluasi di kelas XII MIPA 6 sebesar 28.30\% dengan skor terbanyak yang diperoleh siswa pada tahapan mengevaluasi mencapai skor 4. Hal ini berarti keterampilan siswa dalam mengevaluasi soal sangat tinggi, dimana siswa pada tahapan mengevalusi siswa mampu memberikan langkahlangkah untuk penyelesaian soal, dan dapat melaksanakan rencana sesuai rumus dan perhitungan untuk selanjutnya menarik kesimpulan. Sebagian besar siswa mampu menyelesaikan langkah-langkah penyelesaian soal dengan baik dan benar serta mampu untuk memberikan kesimpulan. Wawancara dengan siswa memberikan informasi bahwa dengan keterampilan mengevaluasi bahwa siswa dengan keterampilan tinggi dan sedang mengerti dengan rumus yang digunakan dan mampu memberikan kesimpulan dengan tepat, tetapi siswa dengan keterampilan rendah memberikan informasi bahwa masih kurang paham dengan rumus yang digunakan sehingga bisa atau tidaknya mengerjakan soal tergentung pada permasalahan yang diberikan. Sehingga dapat diketahui bahwa siswa kelas XII MIPA 6 pada tahapan mengevaluasi mampu melaksanakan perhitungan permasalahan sesuai dengan langkah-langkah penyelesaian yang telah dibuat serta memberikan kesimpulan.

Presentase rata-rata tahapan mengkreasikan di kelas XII MIPA 6 sebesar $13.68 \%$ merupakan presentase terendah dibandingkan tahapan lain. Skor terbanyak dicapai pada tahapan mengkreasikan adalah skor 2. Hal ini menunjukkan bahwa keterampilan mengkreasikan siswa sedang dimana sebagian besar siswa mampu merancang namun belum mampu memadukan informasi dari tahapan menganalisis dan tahapan mengevaluasi dengan tepat sehingga terdapat kesalahan dalam memperoleh dan menulis jawaban. Berdasarkan wawancara dengan siswa kelas XII M IPA 6 diperoleh bahwa siswa mengerti dengan tahapan mengkreasikan, dengan tahapan mengkreasikan siswa dapat merancang dan memadukan informasi atau data dari tahapan menganalisis dan mengevalusi sehingga siswa juga dapat mengkoreksi kembali apakah rumus, jawaban, dan perhitungan yang dikerjakan benar. Tetapi pada kenyataannya sebagian siswa belum mampu 
melalukan tahapan mengkreasikan. Sehingga dapat diketahui bahwa siswa kelas XII MIPA 6 pada tahapan mengkreasikan tidak terbiasa menggunakan langkahlangkah yang runtut dalam mengkreasikan soal walaupun penting untuk mengetahui penyelesaian soal benar atau tidak.

\section{KESIMPULAN}

Berdasarkan analisis data dan pembahasan dapat disimpulkan bahwa presentase rata-rata keterampilan berpikir tingkat tinggi siswa dalam menyelesaikan soal Ujian Nasional (UN) Fisika SMA pada materi medan magnet sebagai berikut: tahap menganalisis sebesar $33.13 \%$, tahap mengevaluasi sebesar $29.77 \%$, dan tahap mengkreasikan sebesar $21.05 \%$. Tahap menganalisis memiliki presentase yang besar sehingga menunjukkan siswa mampu menguraikan informasi (diketahui dan ditanya) serta langkah-langkah penyelesaian soal yang diberikan. Sedangkan tahap mengkreasikan memiliki presentase yang rendah sehingga menunjukkan siswa tidak terbiasa memeriksa kembali jawaban sesuai data yang diketahui dengan langkah-langkah yang runtut. []

\section{REFERENCES}

A bdullah, M. 2007. Fisika Dasar II. Bandung: ITB

Abdurrahman, Kusuma, M.D,. Rosidin, U., dan Suyatna, A. 2017 The Development of Higher Order Thinking Skills (HOTS) Instrumen Assesment in Physic Study. Pp 26-32 In: Assesment of Higher Order Thinking Skills. Schraw, Gregory, Robinson, D. H. Inormatoin Age Publishing. Amerika

Anderson, L. W., Krathwohl, D R., Airasian, P. W ., Cruikshank, K. A., Mayer, R. E., Pintrich, P. R., et al. 2001. A Taxonomy for Learning, Teaching, and Assissing: A Revision of Bloom's Taxonomy of Educational Objectives. N ew York: Longman 
Anggiat. M dan Sri. H. 2001. Pemberdayaan Sumber Daya Manusia. Jakarta: Lembaga Administrasi Negara Republik Indonesia

Arends, Richard I, 2013. Belajar untuk Mengajar Edisi 9. Jakarta: Salemba Humanika

Arikunto, Suharsimi. 2009. Dasar-Dasar Evaluasi Pendidikan. Jakarta: PT Bumi A ksara

Arsyad, A. 2002. M edia Pembelajaran. Jakarta: Rineka Cipta.

Bektiarso, S. 2000. Pentingnya Konsepsi A wal dalam Pembelajaran Fisika. Jurnal Saintifika. Vol. 1(1): 11-20

Depdiknas. 2007. Pedoman Pengembangan Bidang Seni di Taman Kanak-kanak. Jakarta

Djamarah, S.B., Azwan, Z. 2010. Strategi Belajar M engajar. Jakarta: Rineka Cipta

Depdiknas. 2006. Kurikulum Tingkat Satuan Pendidikan. Jakarta: Depdiknas

Dimyati, dan M ujiono. 2006. Belajar dan Pembelajaran. Jakarta: PT Rineka Cipta

Ersoy, E. dan Gurner. P. 2015. "The Pace of Problem Solving and Mathematical Thinking in The Mathematical Teaching", dalam The Online Journal of New Horizons in Education. Vol 5(1): 120-130

Fathoni. 2006. Metodologi Penelitian dan Teknik Penyusunan Skripsi. Jakarta: PT Rineka Cipta

Giancoli, D.C. 2014. Fisika Prinsip dan A plikasi Edisi Ke-7 Jilid 2. Jakarta: Erlangga

Gora, W . \& Sunarto. 2010. Pakematik. Jakarta: PT Elex M edia Komputindo.

Hadi, Sutarto dan Radiyatul. 2014. Metode Pemecahan Masalah untuk Mengembangkan Kemampuan Siswa dalam Pemecahan Masalah $M$ atematis di Sekolah M enengah Pertama. Jurnal Pendidikan M atematika. Vol. 2(1): 53-61

Hamalik, O. 1999. M edia Pendidikan . Bandung: Citra A ditya.

Hamzah dan Masri Kuadrat. 2009. Mengelola Kecerdasan dalam Pembelajaran sebuah Konsep Pembelajaran Berbasis Kecerdasan. Jakarta: Bumi A ksara 
Herdiansyah, Haris. 2013. Wawancara, Obeservasi, dan Focus Group: Sebagai Instrumen Penggalian Data Kualitatif. Jakarta: PT. Rajagrafindo Persada

Hobri. 2010. Metodologi Penelitian Pengembangan (Aplikasi pada Penelitian Pendidikan M atematika). Jember: Pena Salsabila

Kementerian Pendidikan dan Kebudayaan. 2014. IImu Pengetahuan Alam (Buku Guru). Jakarta: Kementerian Pendidikan dan Kebudayaan.

Komarudin. 2016. Analisis Siswa dalam Pemecahan Masalah Matematika pada Materi Peluang Berdasarkan High Order Thinking dan Pemberian Scaffolding. Jurnal Pendidikan, Komunikasi, dan Pemikiran Hukum Islam, Vol.8(1) ISSN 1978-4767: 198-213

Krulik, S,. \& Rudnick, J. A. 1999. “Innovate Task to Improve Critical dan Creavtive

Thinking Skill”, dalam Stiff L.V. dan Curcio FR (ed.), Developing M athematic Reasoning in Grades K-12, V irginia: Y earbook NCTM

Kurniati, Dian. 2016. Kemampuan Berfikir Tingkat Tinggi Siswa SMP di Kabupaten Jember Dalam Menyelesaikan Soal PISA. Penelitian dan Evaluasi Pendidikan Vol.20(2): 142-155

Lewy., Zulkardi., dan Aisyah N., 2009. Pengembangan Soal Untuk Mengukur Kemampuan Berpikir Tingkat Tingkat Tinggi Pokok Bahasan Barisan dan Deret Bilangan di Kelas IX Akselerasi SM P Xaverius M aria Palembang. Jurnal Pendidikan Matematika. Vol.3(2): :4-6

Maghfiratun, N, dkk. 2016. Kemampuan Pemecahan Masalah Matematika Siswa SM A bergaya Kognitif Field Dependent. Prosiding Seminar M atematika dan Pendidikan M atematika. ISBN . 987-602-6122-20-9: 230-239

Mardapi, D. 2012. Pengukuran Penilaian \& Evaluasi Pendidikan. Yogyakarta: Nuha M edika

Meleong, Lexy J. 2012. Metodologi Penelitian Kualitatif. Bandung: PT Remaja Rosdakarya

Mitri, H. 2015. Analisis Pembelajaran Keterampilan Berpikir Tingkat Tinggi Pada Mata Pelajaran Ekonomi di SMA 8 Yogyakarta. Skripsi. Yogyakarta: Universitas Sanata D garma 
Perkasa, D.A. 2015. Sistem Ujian Online Essay dengan Penilaian Menggunakan M etode Latent Sematic Analysis (LSA). Jurnal Rekayasa Sistem Informasi. Vol. 1(1): 1-9

Permendiknas No.23 Tahun 2007. Standar Penilaian Pendidikan. Jakarta: Depdiknas

Poerwadarminta. W.J.S. 2003. Kamus Umum Bahasa Indonesia. Jakarta: Balai Pustaka

Prasetyani, Etika., dkk. 2016. Kemampuan Berpikir Tingkat Tinggi Siswa XI Dalam Pembelajaran Trigonometri Berbasis Masalah di SMAN 18 Palembang. Jurnal Gantang Pendidikan M atematika FKIP, V ol.1(1): 31-40

Puspendik Balitbang Kemendikbud. 2017. Pemanfaatan Hasil Ujian Nasional 2016/2017 untuk Perbaikan M utu Pendidikan. Jakarta: Kemendikbud

Robbins, S.P dan Timothy A.J. 2009. Perilaku Organisasi . Jakarta: Salemba Empat

Rofiah E., Aminah S.N., dan Ikawati E.Y. 2013. Penyusunan Instrumen Tes Kemampuan Berpikir Tingkat Tinggi Fisika pada SM P. Jurnal Pendidikan Fisika. Vol.1(2): 17-22

Ruseffendi. 2006. Pengantar Kepada Membantu Guru Mengembangkan Kompetensinya dalam Pengajaran M atematika. Jakarta: Kemendikbud

Rusman. 2012. Belajar dan Pemebelajaran Berbasis Komputer M engembanhgkan Profesionalisme Guru Abad 21. Bandung: ALFABETA

Saputra, H. Dafik., \& Diah, N. 2014. Soal Matematika dalam PISA Kaitannya dengan Literasi M atematika dan Keterampilan Berfikit Tingkat Tinggi. In Prosiding Seminar Nasional M atematika. Jember

Schemerhorn Jr. dkk, 2007. Organizational Behavior, USA: Atpala, Inc.

Soekamto, T. 1996. Teori Belajar. Jakarta: Universitas Terbuka.

Subagyo, P. Joko. 1997. M etode Penelitian: Dalam Teori dan Praktek. Jakarta: Rineka Cipta

Sugiyono. 2011. M etode Penelitian Kuantitatif , Kualitatif, dan R\&D. Bandung: CV Alfabeta 
Young, H.D., dan Fredman, R.A. 2010. Fisika Dasar Edisi Ketujuhh 2. Jakarta: Erlangga 